\title{
How is Moral Hazard Related to Financing R\&D and Innovations?
}

\author{
Ozgur Arslan-Ayaydin ${ }^{1}$, Darold Barnum², Mehmet Baha Karan², Atilla \\ Hakan Ozdemir ${ }^{4}$,
}

\begin{abstract}
:
This study investigates which corporate governance and firm-specific characteristics lead firms to be prone to ex-post moral hazard by misallocating the funds that they specifically borrowed for financing their $R \& D$ activities. We study 106 firms that received a specially designed loan by a Turkish government to be invested only in $R \& D$ and technological innovations. We find that as the size of the loan increases firms are less prone to moral hazard. For family firms our results support the agency theory. For large shareholders, initially our results are aligned with the agency theory but after controlling for the loan size our results hold for the stewardship theory. We also find that as amount of the loans increases relative to size of firms, the performance of projects financed by these loans plummets. Finally, we show that moral hazard related to $R \& D$ and innovation activities varies across industries.
\end{abstract}

Key Words: Innovations, $R \& D$, Moral Hazard, Corporate Governance, Agency Theory, Stewardship Theory

JEL Classification : G14, G20

\footnotetext{
${ }^{1}$ Department of Finance, University of Illinois at Chicago, Chicago Illinois 60607, United States, e-mail: orslan@uic.edu 2 Department of Information Decision Sciences, University of Illinois at Chicago, Chicago Illinois 60607, United States, e-mail: dbarnum@uic.edu 3 Hacettepe University, Ankara 06800, Turkey, e-mail: mbkaran@hacettepe.edu.tr 4 Turkiye Teknoloji Gelistirme Vakfi (TTGV), Bilkent, Anakara 06800, Turkey, e-mail: ahozdemir@gmail.com
} 


\section{Introduction}

The moral hazard has a potential to arise through the information asymmetry between suppliers of funds to Research and Development (R\&D) and technological innovation projects ${ }^{2}$, and the borrowing firms owning these projects (Svensson, 2013). Here, the wealth-constrained firm controls the allocation of the borrowed funds but the investment effort put to the $R \& D$ activities is unobservable to the supplier of funds. This information asymmetry exacerbates the interest asymmetry and thus creates moral hazard if insiders divert cash flows from external funds to their own benefits instead. Moreover, the information asymmetry is further reinforced, as firms are reluctant to reveal the progress of their $R \& D$ projects with a fear of spillovers to competitors due to non-excludability (Anton and Yao, 1998).

The specific research objective of this study is to investigate which corporate governance and firm-specific characteristics lead firms to be prone to ex-post moral hazard by misallocating the funds that they specifically borrowed for financing their R\&D activities. We study 106 firms that have received a specially designed loan by Turkish government to be invested in their R\&D activities. Here, the supplier of funds is not a profit-seeker agent but a performance-seeking agent. The long-term objective of the government to lend this loan is increasing the performance and uniqueness of goods produced in the domestic market and ultimately contributing to the solution of the country's chronic current account deficit problem. Moral hazard is a special case of information asymmetry where the decision of one party with superior information is at the detriment of another after a transaction has taken place. In our case, after this specially designed loan by the government is acquired, the decision to use this loan efficiently belongs to the firm, which has superior information and do not carry the full burden of potential losses. Through establishing a link between moral hazard and efficient usage of these loans, we also contribute to literature by testing the two contradictory theories, namely "stewardship theory" and "agency theory".

For our study, another factor exacerbating the moral hazard problem is, the loans given out to these firms by the Turkish government have longer maturity compared to other sources of external finance available to them. However, debt with shorter

${ }^{2}$ As a definition, R\&D means commercializing a product or production technology, developed through using the knowledge in accordance to the demand from market. Whereas technological innovation is related with remodelling, an already existing product or improving a good or service through advancing its ease of usage. Henceforth, R\&D will be used as term encompassing both $R \& D$ and technological innovation activities. 
maturity requires more frequent negotiations therefore provides more monitoring so that lenders can protect their claims from the borrower's moral hazard incentive (Arslan and Karan, 2006; Aren at al. 2012). Consequently, these loans have less potential to play an effective role in pre-committing investors to punish the low efforts of firms.

To our knowledge, there is no prior study looking at the direct role of moral hazard in financing R\&D and innovations. The closest to ours is the study by Svensson (2013) who focuses on the nature of the contract terms as a remedy for the moral hazard arising between owners of the patents and their external financiers. Other studies tackle the moral hazard between entrepreneurs and venture capitalists. Chan et al. (1990) explain the optimal transition of control between entrepreneur and venture capitalist in a model with initial uncertainty about the skill of the entrepreneur. Similarly Bergemann and Hege (1998) states that optimal contract between entrepreneur and venture capitalist should be different from a standard debt contract given that entrepreneur's effort is not verifiable.

Our results show that as the size of the loan increases firms are less prone to moral hazard. For family firms, our results support the agency theory. For large shareholders, initially our results are aligned with the agency theory but after controlling for the loan size our results hold for the stewardship theory. Finally we find that as the amount of loan increases relative to the size of a firm, the performance of projects financed by these loans fall and the performance varies across different industries.

This article is organized as follows; the next section explains the motivation of this study and builds hypotheses within the concept of moral hazard. Section II introduces the data and the methodology of the study whereas Section III discusses the results and finally the next section concludes this article.

\section{Motivation}

The recent speed of growth in capital allocation by both developed and developing nations to $R \& D$ has increased the importance of providing more insight on these activities (Thomas et al. 2011). Firms investing in R\&D are found to increase their market share and slash their unit production costs and thereby boost productivity and efficiency (Yang and Huang, 2013). R\&D and innovation activities have broader effects than the individual firm level because they not only create a value for the firm from which they originate, but also they are important for the other actors that interact and cooperate with the firm in the innovation ecosystem (Fisher, 1999).

As an emerging market, Turkey globally ranks at the midlevel in terms of R\&D activities. In specific, as of 2008, the ratio of domestic patent applications to GDP (in billions of $\$$ ) is 2.5 and ranks at $39^{\text {th }}$ out of 40 countries (WIPO, 2010). For the 
same year, the ratio of domestic patent applications to R\&D expenditures (in millions of $\$$ ) is 0.4 , ranking Turkey $23^{\text {rd }}$ out of 40 countries (WIPO, 2010). However R\&D activities of Turkish companies have a particular significance for the country's overall economy given that the high economic growth, which was $9 \%$ in 2010, is fueled by the rising consumption leading to chronic current account deficits in Turkey's trade balance. R\&D activities are a way to boost the domestic production in order to feed the increasing domestic consumption and escalate exports relative to imports and hence curb the current account deficit.

Previous literature establishes a link between corporate governance structure, and R\&D expenditures. For example, Baysinger et al. (1991) show that corporate R\&D strategy is one source of conflict of interest between agents and principals of the firms. Specifically, R\&D activities are characterized as being high risk-high return and hence attractive to principals. However agents are rather reluctant to invest in the $R \& D$ activities because such innovative projects have a high failure potential and do not yield consistent returns. Chung et al. (2003) also report a positive relationship between good corporate governance practices and efficient R\&D investments. Overall, in these studies the moral hazard problem is undertaken as a conflict of interests between shareholders (owners) and managers (controllers).

We expect that this specially designed loan provide a good opportunity to test the moral hazard between a creditor and a borrowing firm. As indicated by Arslan and Umutlu (2005), Turkish SMEs frequently experience borrowing constraints due to chronically high level of real interest rates. Moreover debt maturity of corporate sector in Turkey is found by Aydin et al. (2006) to be very short compared to those of other emerging economies. Nevertheless, the heavy reliance of Turkish firms on short term debt instruments make them vulnerable to interest rates leading to rollover risk. As indicated in the previous section, these government loans, actually granted for the sole purpose of financing projects related with R\&D and innovations, have relatively longer maturities and subsidized interest rates compared to other debt instruments available for our sample firms. For this reason when the companies, particularly those that are more prone to incentive problems, receive these loans it is likely that they are invested in areas activities that are not necessarily related to R\&D.

Moral hazard problem is expected to be different for various kinds of firms. Family managed firms (henceforth, family firms) are one of the most distinct corporate governance structures. The relationship between family firms and R\&D investments can be investigated through two conflicting theories; namely, stewardship theory and agency theory. According to the stewardship theory, family firms act with altruism for the benefit of the entire organization and its stakeholders (Davis et al, 1997). Moreover because the reputation and the honor of the family name are tied to the continued success of the firm, family firms have an emotional investment in their 
companies (Bubolz, 2001). If the stewardship theory holds we expect family firms to use these specially designed R\&D loans more efficiently than the non-family firms, because family firms concentrate on long term survival and prosperity of the company rather than extracting private benefits at the expense of other shareholders.

On the contrary, according to the agency theory, management of family firms focuses on personal benefits rather than the impacts of their decision on their company's short and long term success. In family firms, managers are the members of a controlling family and they are neither closely monitored nor controlled by other family members. Furthermore, managers of family firms are not chosen on a search for best candidate but on a basis of personal relationships (Brunello, et al. 2003). For these managers, financial results of the company do not have an impact on keeping their jobs (Prencipe et al. 2008). Moreover, La Porta et al. (1999) and Claasens et al. (2000) report that corporate governance problems are prevalent in family firms in countries with weak legal protection and Turkey is indicated as one of them. For this reason, agency conflict in family firms takes place as between controlling and the minority shareholders, who can be expropriated by opportunistic behavior of the managers/owners (Morck et al, 1988). Consequently, if agency theory holds, our findings will show that family firms expropriate shareholder wealth through misallocation of resources hence not using these specially designed loans efficiently.

Large shareholders are also one other significant element of the corporate governance structures. Having a dominant shareholder, who as a single person maintains a controlling stake in a company, is similar to being a family firm and here we also face with the conflicting expectations in regarding the "stewardship theory" and "agency theory". According to the former theory, large shareholders personally identify themselves with the firm through internalizing its mission (Sundaramurthy and Lewis, 2003). We expect that as the percentage of ownership of the largest shareholder in a firm increases, the firm uses these loans efficiently. However, according to the agency theory when ownership is concentrated in the hands of a dominant shareholder, typical governance mechanisms have potential to be ineffective. In this case, the firms are exposed to the entrenchment problem, which is a situation that large shareholders have the power to pursuit their own interests rather than those of other shareholders (Morck, 2005). This is called by Villalonga and Amit (2006) as "Type II Agency Problem" because large shareholders have more power to control the assets and on the decisions given for the firms, than minority shareholders. Similarly, Santos et al. (2013) provide evidence that large shareholders expropriate minority shareholders through selfdealing transactions such as equity, cash flow and asset tunneling.

The last corporate governance structure that we analyze within this context is the concentration of ownership by shareholders, for which the literature provides a 
considerable support for the agency theory ${ }^{3}$. It is widely shown that relationship between self-disciplinary mechanisms and ownership concentration is positive because then incentives of controllers are more aligned. For instance, Baysinger et al. (1991) indicate that as the concentration of ownership increases the incentives to monitor the managerial innovative efforts rise as well. Aligning with this, Lee and O'Neill (2003) find that stock concentration is positively related to the R\&D to sales ratio in US firms. We expect a positive relationship between performance of the projects financed with these loans and ownership concentration in a firm given that agents will have less power for opportunistic behavior and excessive perk consumption.

We also control for the size of the loan granted to a firm in order to engage in R\&D activities. Jaffee and Stiglitz (1990) state that loan size chosen by the lender directly affect borrower behavior, and in our case this is the moral hazard. Khalil and Parigi (1998) indicate that as the amount of loan granted increases, the ability of lenders to enforce compliance with the terms of the contract strengthens and this obliges the firm to use the loan efficiently. We hypothesize that as the loan size increases firms utilize these loans in more R\&D efficient areas.

Van Osnabrugge (2000) identifies the importance of industry sector in terms of agency-theory based analysis given that R\&D activities significantly differ across industries. Therefore we also incorporate industry specification of companies to our estimations given that every industry is under a different market structure, which determines the severity of moral hazard Specifically, firms in industries with more competitive market structures are expected to be less engaged in extracting private benefits.

Lastly, in our analyses we study how moral hazard is related with being either a limited liability company (LLC) or a sole proprietorship. In LLCs, owners of the companies are not responsible to the liabilities of the firm with their personal assets. Whereas, sole proprietorship is a business owner and when the firm fails creditors are entitle to force the sale of not only the business property but also the owner's personal assets to satisfy their claims. Therefore, there is no legal distinction between personal assets of sole proprietorship and liabilities of the business. We expect to reach to differing results in terms of moral hazard between sole proprietorship and LLCs.

\section{Data and Methodology}

\footnotetext{
${ }^{3}$ See Zhang (1998) for a broad review on how ownership concentration is related with the agency theory.
} 
The source of the data for this study is 749 firms, which received these R\&D loans by Technology Development Foundation of Turkey (TTGV; Türkiye Teknoloji Geliştirme Vakfi) between the years 1991 and 2009. TTGV is a non-profit organization founded in 1991 through an international loan agreement between the Turkish government and the World Bank. These loans are granted under the classifications of R\&D supports, innovations and technological entrepreneurship supports. TTGV accepts loan applications from domestic firms twice a year and the granted loans may total up to $\$ 1,000,000$ with a stipulation that firms also put a certain amount of cash commitments to their projects as well. The duration of the project is not expected to exceed two years and the repayment of the loan to TTGV is required to be completed in 3.5 years. At the end of the investment period the borrowing firms are inspected by the experts of TTGV.

Intuitively, initial number of 749 available observations is higher than the actual number of borrowing firms due to the fact that some firms are likely to be supported for multiple projects. After controlling for the multiple borrowings, total number of observations further reduces to 547 because, additionally, some firms that are liquidated, taken over or acquired are eliminated. Due to inconsistencies in data, and after truncating the extreme values, observation window is narrowed to the period starting from 2004 and ending at 2008 and therefore total number of target firms is further reduced to 197 firms. These firms are lent these loans by TTGV either in 2004 or 2005 . The corporate governance and firm-specific data, which constitute the independent variables in our analyses) of these firms are obtained through fax and email and the response rate is $54 \%$, which caused the total number of observations to fall to 106 firms.

It is indicated by Hashimoto and Haneda (2008) that the major difficulty in measuring the success of R\&D and innovative activities is due to the fact that while resource inputs can clearly be identified, it is difficult to choose the key outputs. Therefore, we construct a dependent variable that is an aggregation of ten distinct proxies for output success. A firm is scored on each of the ten criteria, on an integer scale from 1 to 5, according to how well it used this specially designed loan by TTGV towards its R\&D and innovation activities for the criterion involved. So, the dependent variable can be considered as a measure of the average performance by a firm in transforming its loan into successful R\&D and innovation. This standard scaling was performed on TTGV to firms that borrowed this loan either in 2004 or 2005, based on 2008 data. The scaling is conducted by our co-author Hakan Özdemir, who is an inspector for the TTGV and whose expertise is in making decisions about firms' success.

The scores of the ten indicators are aggregated into one measure that has an integer value from 1 to 5 , rounding to the nearest whole number when necessary, in order to avoid imputing more accuracy to the summary measure than is actually the case. 
This summary measure of a firm's performance in utilizing the loan in its $\mathrm{R} \& \mathrm{D} /$ innovations investments serves as the dependent variable in the regressions in this article.

Because this dependent variable is a proxy for a firm's efficient use of the government loan, its expected value will be lower for those firms characterized by factors that increase moral hazard. For example, if it were the case that firms with a single individual owning the majority of the equity are found to have lower scores on the dependent variable than expected by chance, then we could conclude that firms under the majority control of one person face a higher moral hazard than those not so classified. That is, since the dependent variable measures a firm's success in utilizing a loan to improve its R\&D performance, then firm characteristics that decrease the estimated value of the dependent variable to a statistically significant degree would indicate that such characteristics increase moral hazard.

The ten criteria and specifications for placing each on a scale of 1 to 5 are shown in Appendix 1, and the actual values assigned are shown in Appendix 2. According to this table, having a mean value of 2.777 of a scale of 1 to 5 , firms in our dataset are moderately successful in utilizing these loans as stipulated.

Table 1. Detailed Statistics about Sample Firms

\begin{tabular}{|l|c|c|c|c|}
\hline Variables & Mean & $\begin{array}{c}\text { Standard } \\
\text { Deviation }\end{array}$ & Minimum & Maximum \\
\hline Loan Performance & 2.777 & 1.441 & 1 & 5 \\
\hline Loan Size & $278,867.10$ & $222,987.10$ & 29,013 & 994,417 \\
\hline$L S / T A$ & 0.175 & 0.110 & 0.001 & 0.624 \\
\hline Family Firm & 0.359 & 0.482 & 0 & 1 \\
\hline Large Shareholder & 0.566 & 0.242 & 0.1632 & 1 \\
\hline Concentration & 4.825 & 6.004 & 1 & 57 \\
\hline LLC & 0.340 & 0.476 & 0 & 1 \\
\hline Technology & 0.136 & 0.344 & 0 & 1 \\
\hline
\end{tabular}

Notes: This table provides detailed statistics about 106 firms that we analyze in this study. Loan Performance is a scale ranging from 1 to 5, the firms using the loans least efficiently takes the value of 1 and the ones that use the loan the most efficiently takes the value of 5. Loan Size is the amount of loan granted to a firm in either 2004 or in 2005 and it is denominated in Turkish Lira. LS/TA is the ratio of the loan size to the total assets of the firm. Family Firm is a dummy variable taking the value of 1 if a family member is a controller of the firm and zero otherwise. Large Shareholder shows the ownership percentage of the largest shareholder of the company. Concentration is the total number of shareholders in a company. $L L C$ is a dummy variable taking the value of zero if a firm is a limited liability company and one if a firm is a sole proprietorship. Technology is another dummy variable taking the value of 1 if the firm is located the technological development area and zero otherwise. 
Table 1 provides detailed statistics about the firms in our data set. Loan Size is the amount of loan granted to a firm in either 2004 or in 2005 and it is denominated in USD. The standard deviation of the Loan Size variable shows that there is large variation in the value of loans granted to firms. For that reason we include, the variable $L S / T A$, which measures the ratio of the loan size to the total assets of the firm. As for corporate governance attributes, most of the firms in our data set are not family firms and the average percentage of ownership by the dominant shareholder, which is shown as the Large Shareholder and measured as the percentage of shareholder of the largest shareholder in a company, is around $57 \%$ and finally Concentration stands for the ownership concentration in a firm, measured by the number of shareholders in a firm and its average value is around 5 with a relatively high standard deviation ${ }^{4}$.

Our results also show that around $66 \%$ of firms in our sample is sole proprietorship. Furthermore, Technology is another dummy variable taking the value of 1 if the firm is located the technological development area and zero otherwise. Technological development areas in Turkey are designated as the ones where firms only engage in business activities related with R\&D and technological innovations. These firms take advantage of supports, subventions and tax exemptions from the local government, and these advantages play a considerable role in decreasing their operating leverage. However the activities of firms located in these areas are also under a more scrutiny and monitoring by government and hence we expect a positive (negative) association between having been located in the area and the R\&D performance (moral hazard). The table shows that around 14\% of the firms in our data set are located in the technological development areas in Turkey Intuitively, intensity of the R\&D activities of firms differs in accordance to which industry they are in. The highest number of firms in our data set belongs to the machinery and equipment industry, followed by electric \& electronic, software, materials, chemicals and finally bio-agriculture industries. The year of the observation for each variable is 2008 except for the Loan Size and LS/TA, which belong to years 2004 or 2005 depending on the date when the loan is granted.

\footnotetext{
${ }^{4}$ Our multivariate results still hold when ownership concentration is measured as the sum of ownership percentages of the highest three owners.
} 
Table 2.Correlation Coefficient across Variables

\begin{tabular}{|c|c|c|c|c|c|c|c|c|c|c|c|c|c|c|}
\hline & $\begin{array}{c}\text { Loan } \\
\text { Per/nce }\end{array}$ & $\begin{array}{l}\text { Bio- } \\
\text { Agro }\end{array}$ & $\mathrm{E} \& \mathrm{E}$ & $\begin{array}{c}\text { Softwa } \\
\text { re }\end{array}$ & Chemistry & Mach-Eq. & $\overline{\text { LLC }}$ & Tech. & \begin{tabular}{l|} 
Family \\
Firm
\end{tabular} & Conct. & $\begin{array}{l}\text { Large } \\
\text { Shrhldr }\end{array}$ & $\begin{array}{l}\text { Loan } \\
\text { Size }\end{array}$ & LS/TA & Materials \\
\hline $\begin{array}{l}\text { Loan } \\
\text { Performance }\end{array}$ & 1.00 & & & & & & & & & & & & & \\
\hline Bio-Agro & 0.17 & 1.00 & & & & & & & & & & & & \\
\hline $\mathrm{E} \& \mathrm{E}$ & 0.01 & -0.15 & 1.00 & & & & & & & & & & & \\
\hline Software & -0.14 & -0.15 & -0.26 & 1.00 & & & & & & & & & & \\
\hline Chemistry & 0.05 & -0.09 & -0.16 & -0.16 & 1.00 & & & & & & & & & \\
\hline Mach-Eq. & 0.16 & -0.12 & -0.20 & -0.20 & -0.13 & 1.00 & & & & & & & & \\
\hline LLC & -0.11 & 0.02 & -0.11 & -0.06 & -0.15 & 0.13 & 1.00 & & & & & & & \\
\hline Technology & -0.04 & -0.12 & -0.06 & -0.64 & -0.13 & -0.16 & -0.17 & 1.00 & & & & & & \\
\hline Family Firm & -0.14 & 0.01 & 0.07 & -0.27 & -0.02 & 0.18 & 0.28 & -0.18 & 1.00 & & & & & \\
\hline Conct. & 0.08 & -0.06 & -0.07 & 0.16 & -0.02 & 0.01 & -0.27 & 0.27 & -0.14 & 1.00 & & & & \\
\hline $\begin{array}{l}\text { Large } \\
\text { Shareholder }\end{array}$ & -0.016 & 0.03 & -0.09 & -0.06 & -0.10 & 0.08 & 0.28 & 0.03 & -0.06 & -0.19 & 1.00 & & & \\
\hline Loan Size & 0.25 & -0.11 & 0.08 & 0.07 & 0.04 & -0.10 & -0.28 & 0.34 & -0.11 & 0.03 & -0.06 & 1.00 & & \\
\hline LS/TA & -0.26 & -0.11 & -0.07 & 0.24 & -0.14 & -0.04 & 0.13 & 0.04 & -0.06 & -0.10 & 0.11 & 0.07 & 1.00 & \\
\hline Materials & 0.16 & -0.12 & -0.21 & -0.20 & -0.12 & -0.25 & 0.09 & -0.15 & 0,17 & 0.13 & 0.07 & -0.09 & -0.08 & 1.00 \\
\hline
\end{tabular}


Notes: This table provides correlation coefficients across variables belonging to 106 firms that we analyze in this study. Loan Performance is a scale ranging from 1 to 5 , the firms using the loans least efficiently takes the value of 1 and the ones that use the loan the most efficiently takes the value of 5 . Loan Size is the amount of loan granted to a firm in either 2004 or in 2005 and it is denominated in Turkish Lira. LS/TA is the ratio of the loan size to the total assets of the firm. Family Firm is a dummy variable taking the value of 1 if a family member is a controller of the firm and zero otherwise. Large Shareholder shows the ownership percentage of the largest shareholder of the company. Conct. stands for the concentration of ownership and is measured as the total number of shareholders in a company. LLC is a dummy variable taking the value of zero if a firm is a limited liability company and one if a firm is a sole proprietorship. Technology is another dummy variable taking the value of 1 if the firm is located the technological development area and zero otherwise. Bio-Agro is a dummy variable taking the value of 1 if the firm belongs to the bio-agriculture industry and zero otherwise. E\&E is a dummy variable taking the value of 1 if the firm belongs to the electric-electronic industry and zero otherwise. Software is a dummy variable taking the value of 1 if the firm belongs to the software industry and zero otherwise. Chemistry is a dummy variable taking the value of 1 if the firm belongs to the chemistry industry and zero otherwise. Mach-Eq is a dummy variable taking the value of 1 if the firm belongs to the machine-equipment industry and zero otherwise. Materials is a dummy variable taking the value of 1 if the firm belongs to the materials industry and zero otherwise. 
Table 2 shows the correlation matrix across the variables in our analyses and there is not a multi-co linearity problem across our variables.

\section{Results}

Table 3 shows the three regression equations that we estimate, and the results for our analyses. In all three regressions, we use Huber-White sandwich estimator for robust variance-covariance estimations and in order to correct for heteroskedasticity.

Table 3.Regression Results

\begin{tabular}{|c|c|c|c|}
\hline & Model 1 & Model 2 & Model 3 \\
\hline Independent Variables & Coefficient & Coefficient & Coefficient \\
\hline \multirow[t]{2}{*}{ Constant } & $2.745 * * *$ & $2.704 * * *$ & $3.553 * * *$ \\
\hline & $(5.48)$ & $(5.22)$ & $(6.12)$ \\
\hline \multirow[t]{2}{*}{ Loan Size } & $0.001 * * *$ & $0.001 * * *$ & -0.001 \\
\hline & $(3.83)$ & $(3.24)$ & $(-0.71)$ \\
\hline \multirow[t]{2}{*}{ Loan Size/Total Assets } & $-1.110 * * *$ & $-1.120 * *$ & $-0.884 * *$ \\
\hline & $(-2.61)$ & $(-2.56)$ & $(-2.13)$ \\
\hline \multirow[t]{2}{*}{ Family Firm } & $-0.619 * *$ & -0.517 & $-0.633 * *$ \\
\hline & $(-2.20)$ & $(-1.24)$ & $(-2.31)$ \\
\hline \multirow[t]{2}{*}{ Family Firm*Loan Size } & & -0.001 & \\
\hline & & $(-0.38)$ & \\
\hline \multirow[t]{2}{*}{ Large Shareholder } & $-0.91 *$ & -0.918 & $-2.575 * * *$ \\
\hline & $(-1.73)$ & $(-1.43)$ & $(-2.98)$ \\
\hline \multirow[t]{2}{*}{ Large Shareholder*Loan Size } & & & $0.001 * * *$ \\
\hline & & & $(2.51)$ \\
\hline \multirow[t]{2}{*}{ Concentration } & 0.013 & 0.013 & 0.011 \\
\hline & $(0.72)$ & $(0.71)$ & $(0.56)$ \\
\hline \multirow[t]{2}{*}{ LLC } & 0.234 & 0.239 & 0.303 \\
\hline & $(0.72)$ & $(0.73)$ & $(0.96)$ \\
\hline \multirow[t]{2}{*}{ Technology } & -0.387 & -0.371 & -0.410 \\
\hline & $(-0.73)$ & $(-0.68)$ & $(-0.79)$ \\
\hline \multirow[t]{2}{*}{ Materials } & $1.020 * *$ & $1.029 * *$ & $1.209 * * *$ \\
\hline & $(2.19)$ & $(2.19)$ & $(2.60)$ \\
\hline \multirow[t]{2}{*}{ Bio-Agro } & $1.168^{*}$ & $1.160^{*}$ & $1.288^{* *}$ \\
\hline & $(1.96)$ & $(1.93)$ & $(2.36)$ \\
\hline \multirow[t]{2}{*}{$\mathrm{E} \& \mathrm{E}$} & 0.211 & 0.207 & 0.174 \\
\hline & $(0.62)$ & $(0.61)$ & $(0.53)$ \\
\hline \multirow[t]{2}{*}{ Software } & -0.052 & -0.438 & 0.051 \\
\hline & $(-0.10)$ & $(-0.09)$ & $(0.10)$ \\
\hline \multirow[t]{2}{*}{ Chemistry } & 0.214 & 0.209 & 0.323 \\
\hline & $(0.40)$ & $(0.39)$ & $(0.62)$ \\
\hline $\mathrm{R}^{2}$ & 0.29 & 0.28 & 0.31 \\
\hline
\end{tabular}


This table provides regression results belonging to 106 firms that we analyze in this study. We use Huber-White sandwich estimator for robust variance-covariance estimations and in order to correct for heteroskedasticity. Loan Performance is the dependent variable in the regression a scale ranging from 1 to 5 , the firms using the loans least efficiently takes the value of 1 and the ones that use the loan the most efficiently takes the value of 5. Loan Size is the amount of loan granted to a firm in either 2004 or in 2005 and it is denominated in Turkish Lira. LS/TA is the ratio of the loan size to the total assets of the firm.

Family Firm is a dummy variable taking the value of 1 if a family member is a controller of the firm and zero otherwise. Large Shareholder shows the ownership percentage of the largest shareholder of the company.

Concentration is the total number of shareholders in a company. $L L C$ is a dummy variable taking the value of zero if a firm is a limited liability company and one if a firm is a sole proprietorship.

Technology is another dummy variable taking the value of 1 if the firm is located the technological development area and zero otherwise. Bio-Agro is a dummy variable taking the value of 1 if the firm belongs to the bio-agriculture industry and zero otherwise. $E \& E$ is a dummy variable taking the value of 1 if the firm belongs to the electric-electronic industry and zero otherwise. Software is a dummy variable taking the value of 1 if the firm belongs to the software industry and zero otherwise. Chemistry is a dummy variable taking the value of 1 if the firm belongs to the chemistry industry and zero otherwise.

Materials is a dummy variable taking the value of 1 if the firm belongs to the materials industry and zero otherwise. For the industry variables, the base (and therefore omitted variable to which the others are compared) is Machinery and Equipment, t-statistics are reported in parenthesis. The year of the observation for each variable is 2008 except for the Loan Size and LS/TA, which belong to years 2004 or 2005 depending on the date when the loan is granted. *,** and *** denote significance levels at $10 \%, 5 \%$ and $1 \%$ respectively.

Our results show that as the loan size increases the firms become less prone to moral hazard and use the loans efficiently. Our results align with those of Khalil and Parigi (1988) because we find that as the amount of loan increases the firms become more obliged to abide by the terms of the contract because increased loan amount encourages the monitoring by the lender and this in turn ameliorates the firm's moral hazard problem through inducing the firm to engage in efficient projects. 
Besides, higher is the loan amount higher is the interest cost for the loan, which depletes the benefits of moral hazard of the borrower.

We also find that the larger is the size of the loan that a firm is granted relative to the total assets of the firm the less efficient is the project. This result suggests that the most efficient projects were produced with large government loans to large firms. In other words the smaller firms become are more inclined to moral hazard as the amount of loan they are granted increase.

Our results for both the family firm and having a dominant shareholder in a firm support the agency theory, instead of the stewardship theory. First of all we find that being a family firm is negatively associated with the performance. For that reason family firms are found to be more prone to opportunistic behaviors at the expense of shareholders and hence myopic in allocation of the borrowed funds. Furthermore, despite not having a statistically strong significance, large shareholders are also more inclined to moral hazard as the relationship between the variable and performance scale is found to be negative.

For the concentration of ownership, which is another corporate governance attribute in our analyses, we do not find a statistically significant result. This finding offers that the relationship between moral hazard and R\&D investments cannot be explained through the concentrated or dispersed ownership structure of these firms.

According to the 2010 report of Turkish Council of Science and Research (TUBITAK, 2010) machinery-equipment industries give the highest emphasis on R\&D activities and this industry is ranked as the first in Turkey in R\&D capacity. For this reason, in our analyses machinery-equipment industry is used as the base, and the coefficients for the other industries measure the difference in performance between machinery-equipment and the industry involved. Our results show that the mean efficiencies are greater than the machinery equipment industry for only two industries, namely, materials and bio-agriculture whereas with the others not different from the machinery-equipment industry to a statistically significant degree. In other words, firms in the materials and, to a certain extent, bio-agriculture industries are found to be R\&D efficient and less associated with moral hazard. This result reflects the fact that competitive pressure has a potential to reduce the moral hazard problem (Nygaard and Myrtveit, 2000). Competition in materials industry (any materials used in building, construction, mining, handling) in Turkey is fiercer due to heavy pressure of imports from foreign producers and therefore there is a higher requirement to resort to $R \& D$ activities in order to decrease unit production costs, create a relatively unique product and maintain the market share.

Moreover, materials industry is the most sensitive to economic cycles given that materials are the primary input for the industry sector. Altogether, R\&D activities are helpful in decreasing the price elasticity of demand for the outputs of this 
industry. Besides, in the bio-agriculture sector, there is also a high value added through creating a unique product through $\mathrm{R} \& \mathrm{D}$ investments, and this situation makes the moral hazard more costly for these firms in our case. Bio- agricultural industry has considerable biological science (molecular biology involving genomics, proteomics, recombinant DNA, and supporting informatics technologies) at its foundation, making the industry more open to R\&D activities. Moreover, agricultural sector has a significant role in the Turkey's economy with an annual share of $12 \%$ of the GNP between 2001-2005 (Ozer et al. 2008). However, for the rest of the industries, namely; electric-electronic, software and chemicals we do not detect a higher R\&D performance.

Our results show that, at odds with our initial expectations, firms located in the technological development areas are not found to be more R\&D efficient than the firms that are not located in these areas. Lastly, there is no statistically significant impact of being either a sole proprietorship or a LLC, in which owners are not responsible to the liabilities of the firm with their personal assets, on R\&D performance. In order to further enhance the discussion of our results, in Model 2 we take an interaction between family firms and the loan size with an aim to see if moral hazard in the family firms still persists as the amount of the borrowed loans increases. Here we aim to see if firms still experience an agency threat called as selfcontrol (Jensen, 1998), which is the case when owner managers have incentive to take actions that is likely to harm themselves as well as those around them, despite the loan size grows. However the interaction variable is found to be statistically insignificant and hence does not enable us to conclude that these loans themselves impose a discipline on family firms.

In Model 3, this time we take interaction between the loan size and the large shareholder, in order to find out if the amount of loan plays a disciplinary role on the dominant shareholder to take long term oriented and value-enhancing actions for shareholders, in order words lead them to invest these loans in R\&D efficient areas. This time, our model shows that interaction term in our regression becomes positive and statistically significant. As the amount of the loan increases large shareholders become less prone the moral hazard and more disciplined not to pursuit their own interests at the expense of other shareholders. Therefore after controlling the loan size we find a support for stewardship theory for large shareholders given that as the amount of the borrowed loan increases Type II agency costs disappears because the dominant shareholders are now motivated by altruism and loyalty.

\section{Discussion}

Given the importance of corporate innovation, there needs to be a clarification on the factors that affect a firms' performance in R\&D investments, which determines 
the increase in firm value. However, allocation of funds to R\&D investments does not necessarily lead to higher value if moral hazard is in place. Innovation activities are highly uncertain and skewed. The presence of information asymmetry between suppliers of funds to R\&D activities and the borrowing firms leads us to link corporate governance to R\&D investment outcomes ${ }^{5}$.

As indicated by Hwang et al. (2012), studying the impact of moral hazard on R\&D performance in an emerging market setting is particularly important given that these countries have a weaker tradition for law and order for the protection of shareholder and creditor rights. Shleifer and Vishny (1997) show that corporate governance concepts are influenced by a country's institutional framework such as bankruptcy laws, legal protection of investor and minority rights, control by financial institutions and restrictions on managerial self-dealing. It is now generally agreed that the lessons one can draw from various U.S.-based studies are not necessarily applicable to other countries (Claessens et al., 2002). By contrast, in emerging markets, such as Turkey, large shareholders have higher likelihood to pursue their own interests at the expense of other stakeholders, and family firms are more common. Therefore, agency costs affecting US firms are significantly different from those affecting emerging markets. ${ }^{6}$

Especially for family firms, our results contradict to what is suggested by Munari et al (2010) that the context of suppliers of external finance moderates the relationship between corporate governance practice of companies and their R\&D investments. Specifically, our results on family firms align with how Perez-Gonzalez (2006) associates them with nepotism and managerial entrenchment. Therefore, family utility maximization through these loans is opposed to firm value maximization. Similarly, Block (2012) also finds for US firms that family ownership causes agency costs, leading to lower R\&D intensity.

According to the results, we find that loan size is positively associated with performance of the supported projects. While small-scale R\&D projects are easier to manage, large-scale ones require using a more structured project management methodology. This better management helps to decrease the risk of moral hazard and increases the performance of the project. Vice versa, firms having better project

\footnotetext{
${ }^{5}$ The objective of this study to link corporate governance issues to R\&D efficiency is further boosted by the recent policy debate pointing at the persistence of high executive remuneration packages while weak propensity in Europe to invest in R\&D after the 2008 crisis (van Pottelsberghe, 2011).

${ }^{6}$ See, Minetti (2011) et al. for further discussion.
} 
management capabilities are more willing to apply for and handle large-scale projects.

Another striking finding is that as amount of the loan increases relative to size of a firm, the performance of a project financed by these loans decreases. In other words, loan size no longer functions to mitigate conflicts of interests when it excessive relative to a firm's size. This may be explained by the increased risk tolerance of the firms. Firms having financial difficulties tend to engage in more risky projects (or projects that they may not pursue under normal circumstances) in order to get more returns, thus trying to recover faster. In that case, they are also willing to acquire more debt. However, we are unable to test this prediction due to unavailability of data related to financial problems experienced by our sample firms. Therefore we recommend the test of the relationship between financial constraints and the ratio of loan amount to firm size as an avenue for further research.

\section{Conclusion}

In a recent study by Sapra et al (2014) it is emphasized that the theoretical literature on innovation choices of firms through the corporate governance is still undeveloped. The objective of this study is to shed a light on the association between the concept of moral hazard and efficient usage of funds aimed at R\&D and technological innovation activities of firms from an emerging market. This way we also complement the study of Gugler (2001) indicating that information asymmetry about R\&D projects may discourage creditors from financing innovation activities. To do this we study 106 firms that are granted with a specially designed loan by TTGV to be invested only for their R\&D activities.

Overall our analysis provides evidence that corporate governance is a driving force of a firm's efficient use of these loans. Our initial results lend support to the "agency theory" through family firms and large shareholders, both of which may influence decisions that foster their personal profit or utility but neglect or even harm minority shareholders, yet it is inconclusive for the ownership concentration. We find that loan size is positively associated with performance of the supported projects. After controlling for the loan size for family firms and large shareholders, our results lend considerable support that "agency theory" persists for family firms yet this time the results hold for the "stewardship theory" for firms with dominant shareholders. When the amount of loan is scaled to the total assets of a firm, we find that as the loan size increases relative to the size of a firm and then firms become more prone to moral hazard. We also find that firms in the materials and bio-agriculture industries are more efficient in using these loans in $\mathrm{R} \& \mathrm{D}$ projects. Interestingly, being located in the technologically supported region has no significant impact on the performance of loans. Finally, we do not find a distinction between being a LLC and sole 
proprietorship in terms of the relationship between moral hazard and the outcome of the $R \& D$ investments.

\section{APPENDIX}

\section{Performance Criteria}

1. Project's objective remained consistent from start to end

1 The objective became completely different

2 The objective became substantially different

3 don't know

4 The objective remained substantially the same

5 The objective remained completely the same

2 . Changes that occurred in the implementation process were

1 completely unjustified

2 substantially unjustified

3 don't know

4 substantially justified

5 completely justified

3. Actual costs were ___ than the proposed costs

1 much higher

2 somewhat higher

3 about the same

4 somewhat lower

5 much lower

4 . The project was successfully completed

1 completely false

mainly false

don't really know

mainly true

5 completely true

5. The results of the project were disseminated
1 not at all
2 only a minor amount
3 not a lot, not a little
4 a fairly substantial amount
5 widely disseminated

6. The project results can be commercialized

$\begin{array}{ll}1 & \text { not at all } \\ 2 & \text { only to a minor degree } \\ 3 & \text { more than a little, less than a lot } \\ 4 & \text { to a reasonably substantial degr }\end{array}$

4
5 to a reasonably sub degree

7. As a result of the project firm sales were

1 much lower

2 a little lower

3 about the same

4 a little higher

5 much higher

8. As a result of the project firm costs were

1 much higher

2 a little higher

3 about the same

4 a little lower

5 much lower

9. As a result of the project the firm's net income was

1 much lower

2 a little lower

3 about the same

4 a little higher

5 much higher

10. As a result of the project, the firm's market share was
1 much lower
a little lower
about the same
a little higher

5 much higher 


\section{Performance Estimation Data}

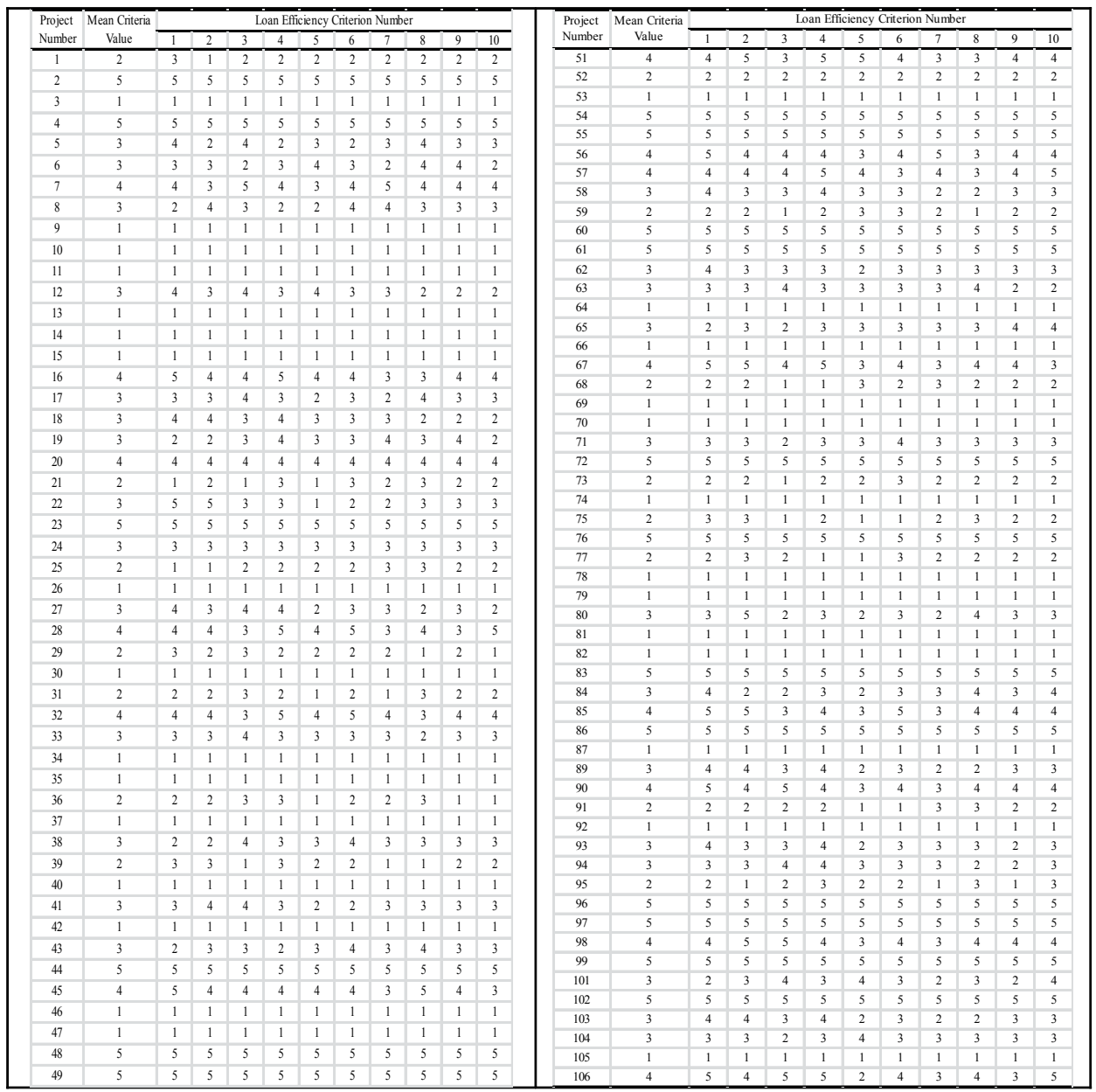

\section{References}

Anton, J.J., Yao, D. A. (1998) "The Sale of Intellectual Property: Strategic Disclosure, Property Rights, and Incomplete Contracts", The Wharton School, University of Pennsylvania: Working Paper.

Aren, S., Alpkan, L., Sezen, B., and Guncu, Z.A. (2012) 'Drivers of Firms' Debt Ratios: Evidence from Taiwanese and Turkish Firms' Journal of Business Economics and Management, 13: 53-70. 
Arslan, Ö. Karan, M.B. (2006) 'Ownership and Control Structure as Determinants of Corporate Debt Maturity: a Panel Study of an Emerging Market.' Corporate Governance: An International Review, 14: 312-24.

Arslan Ö., Umutlu G. (2010) 'Trade Credits and Bank Loans for SMEs in the Textile Sector', Journal of Small Business Entrepreneurship, 22: 383-98.

Aydin, H.I., Kaplan C., Kesiyeli M., Ozman E., Yalcin C. and Yigit S. (2006) 'Corporate Sector Financial Structure in Turkey: a Descriptive Analysis', The Central Bank of The Republic of Turkey, Research and Monetary Policy Department, Working Paper No: 06/07.

Baysinger B.D., Kosnik R.D. and Turk T.A. (1991) 'Effects of Board and Ownership Structure on Corporate R\&D Strategy', The Academy of Management Journal, 34: 205-14.

Bergemann, D., Hege, U. (1998) 'Venture Capital Financing, Moral Hazard, and Learning', Journal of Banking \& Finance, 22, 703-35.

Block, J.H. (2012) 'R\&D Investments in Family and Founder Firms: An Agency Perspective', Journal of Business Venturing, 27: 248-65.

Brunello G., Graziano C. and Parigi B.M. (2003) 'CEO Turnover in InsiderDominated Boards: The Italian Case', Journal of Banking \& Finance, 27: 1027-51.

Bubolz M.M. (2001) 'Family as Source, User, and Builder of Social Capital', Journal of Socio-Economics, 30: 129-131.

Chan, Y.S., Siegel, D., and Thakor, A.V. (1990) 'Learning, Corporate Control and Performance Requirements in Venture Capital Contracts', International Economic Review, 365-81.

Chung K.H., Wright P. and Kedia B. (2003) 'Corporate Governance and Market Valuation of Capital and R\&D Investments', Review of Financial Economics, 12: 161-72.

Claessens S., Djankov S., and Lang L.H.P. (2000) 'The Separation of Ownership and Control in East Asian Corporations', Journal of Financial Economics, 58: 81-112.

Claessens, S., Djankov, S., Fan, J. and Lang, L. (2002) 'Disentangling the Incentive and Entrenchment Effects of Large Shareholdings', Journal of Finance, 57: 2741-2771.

Davis, J.H., Schoorman, F.D., and Donaldson, L. (1997) 'Toward a Stewardship Theory of Management', Academy of Management Review, 22: 20-47.

Fisher, M. (1999) 'The Innovation Process and Network Activities of Manufacturing Firms', Innovation, Networks and Localities (14), Springer-Verlag Berlin: Heidelberg.

Gugler, K. (2001) 'Corporate Governance and Economic Performance', Oxford University Press, Oxford.

Hashimoto A., Haneda S. (2008) 'Measuring the Change in R\&D Efficiency of the Japanese Pharmaceutical Industry'. Research Policy, 37: 1829-1836. 
Havlíček, K., Břečková, P. and Zampeta, V. (2013) "Quality Management as a Part of CRM”, European Research Studies Journal, vol. XVI, Special Issue on SMEs, 15-28.

Hwang, J.H., Kim, M.S. and Chun, S.H. (2012). 'The Role of R\&D and Corporate Governance in Korea: IT Firms Versus Non-IT Firms', Information Technology and Management, 1-13.

Jaffee D., Stiglitz J. (1990) 'Credit Rationing', Handbook of Monetary Economics, 2, 837-888.

Jensen M.C. (1998) 'Foundations of Organizational Strategy', Harvard University Press: Cambridge, $M A$.

Khalil F., Parigi B. (1998) 'Loan Size as a Commitment Device', International Economic Review, 39: 135-150.

La Porta R., Lopez-de-Silanes F., Shleifer A. and Vishny R.W. (1999) 'The Quality of Government', Journal of Law, Economics, \& Organization, 15: 222-279.

Lee P.M., O’Neill H.M. (2003). 'Ownership Structures and R\&D Investments of U.S. and Japanese Firms: Agency and Stewardship Perspectives', Academy of Management Journal, 46: 212-225.

Minetti, R., Murro, P. and Paiella, M. (2011) 'Ownership Structure, Governance and Innovation: Evidence from Italy’, Discussion Paper.

Munari F., Oriani R. and Sobrero M. (2010) 'The Effects of Owner Identity and Financial Markets on R\&D Investments: A Study of Western European Firms", Working Paper.

Morck R., Shleifer, A. and Vishny, R.W. (1998) 'Management Ownership and Market Valuation: An Empirical Analysis', Journal of Financial Economics, 20: 293-315.

Morck, R. (2005) 'A History of Corporate Governance around the World', Chicago, IL: University of Chicago Press.

Nygaard, A., Myrtveit, I. (2000) 'Moral Hazard, Competition and Contract Design, Empirical Evidence from Managerial, Franchised and Entrepreneurial Businesses in Norway', Applied Economics, 32: 349-356.

Perez-Gonzalez, F. (2006) 'Inherited Control and Firm Performance', American Economic Review 96: 1559-1588.

Prencipe A., Markarian G. and Pozza L. (2008) 'Earnings Management in Family Firms: Evidence from R\&D Cost Capitalization in Italy', Family Business Review, 21: 71-88.

Santos, M.S., Moreira, A.C. and Vieira, E.S. (2013) 'Block Holders Presence, Identity and Institutional Context. Are They Relevant for Firm Value?' International Journal of Business Governance and Ethics, 8: 18-49.

Sapra H., Subramanian A. and Subramanian, K. (2014) 'Corporate Governance and Innovation: Theory and Evidence', Journal of Financial and Quantitative Analysis, Forthcoming. 
Shleifer, A., Vishny, R.W. (1997) 'A Survey of Corporate Governance', Journal of Finance, 52: 737-783.

Svensson, R. (2013) 'Publicly-Funded R\&D Programs and Survival of Patents', Applied Economics, 45: 1343-1358.

Sundaramurthy C., Lewis M. (2003) 'Control and Collaboration: Paradoxes of Governance', The Academy of Management Review, 28: 397-415.

Thalassinos, I.E., K. Havlíček and L. Berezkinova (2012) 'Innovation Management and Controlling in SMEs', European Research Studies Journal, Vol. XV, Special issue, 110-123.

Thomas V.J., Sharma S. and Jain S.K. (2011) 'Using Patents and Publications to Assess R\&D Efficiency in the States of the USA', World Patent Information, 33, 4-10.

TUBITAK (2010) 'National Science, Technology and Innovation Strategy 20112016', TUBITAK Department of Science, Technology and Innovation, Ankara.

Van Pottelsberghe, B. (2011) 'Corporate Governance Practices and Companies' R\&D Orientation: Evidence from European Countries', Working Paper.

Van Osnabrugge M (2000) 'A Comparison of Business Angel and Venture Capitalist Investment Procedures: An Agency Theory-Based Analysis', Venture Capital, 2, 91-109.

Villalonga B., Amit R. (2006) 'How Do Family Ownership, Control and Management Affect Firm Value?' Journal of Financial Economics, 80, 385417.

Yang, C.H., Huang, C.H. (2013) 'Is Taiwan's R\&D Productivity in Decline? A Microeconometric Analysis', Journal of Business Economics and Management, 14: $137-155$.

Zhang G. (1998) 'Ownership Concentration, Risk Aversion and the Effect of Financial Structure on Investment Decisions', European Economic Review, 42: 1751-1778. 